Intellectual Foundations of the Nicaraguan Revolution 
THIS PAGE INTENTIONALLY LEFT BLANK 


\title{
Intellectual Foundations \\ of the Nicaraguan Revolution
}

\author{
by DONALD C. HODGES
}

University of Texas Press 
Copyright $(\mathcal{C} 1986$ by the University of Texas Press

All rights reserved

Printed in the United States of America

First Edition, 1986

Requests for permission to reproduce material from this work should be sent to Permissions, University of Texas Press, Box 7819, Austin, Texas 78713-7819.

Library of Congress Cataloging-in-Publication Data

Hodges, Donald Clark, 1923-

Intellectual foundations of the Nicaraguan revolution.

Bibliography: $p$.

Includes index.

I. Sandino, Augusto César, r 895-1934-Political and social views.

2. Nicaragua-History-1909-1937. 3. Frent Sandinista de Liberación Nacional. 4. Nicaragua-History-1937-1979. 5. Nicaragua-History-Revolution, 1979-Influence. I. Title.

FI526.3.S24H63 I $1986 \quad 972.85^{\prime} 05 \mathrm{I} \quad 86-6937$

ISBN 0-292-73838-2

ISBN 0-292-73843-9 (pbk.)

ISBN 978-0-292-77717-0 (library e-book)

ISBN 978-0-292-77728-6 (individual e-book) 